\title{
DOMINANCE OF PARIS-TYPE MORPHOLOGY ON MYCOTHALLUS OF LUNULARIA CRUCIATA COLONISED BY GLOMUS PROLIFERUM
}

\author{
Henrique M.A.C. Fonseca $^{1 *}$; Joana I.L. Ferreira ${ }^{2}$; Ricardo L.L. Berbara ${ }^{3}$; Natalia P. Zatorre ${ }^{3}$ \\ ${ }^{1}$ Centre of Cellular Biology, Department of Biology, University of Aveiro, 3810-193, Aveiro, Portugal; ${ }^{2}$ Faculty of Science, \\ University of Porto, 4169-007, Porto, Portugal; ${ }^{3}$ Universidade Federal Rural do Rio de Janeiro, Departamento de Solo, \\ Seropédica, RJ, Brasil.
}

Submitted: March 14, 2008; Returned to authors for corrections: July 10, 2008; Approved: February 15, 2009.

\begin{abstract}
Microscopic evidence confirms that $L$. cruciata hosting G. proliferum shows major anatomical traits (arbuscules, coils, arbusculate coils and vesicles) generally associated arbuscular mycorrhizal roots and the anatomical morphology of intra-thalli mycelium is predominantly of the Paris-type. Colonised L. cruciata showed a reduction of biomass when compared with axenic plants suggesting a drain of resources towards the fungus and depletion of nutrients required for optimum plant growth. The behaviour of mycothalli regarding available $\mathrm{KH}_{2} \mathrm{PO}_{4}$ indicates that the nutritional stress threshold for phosphorus $(\mathrm{P})$ is above the residual amount of $\mathrm{P}$ already present in Phytage $\mathrm{l}^{\mathrm{TM}}$ and in plant inoculum. These raise the possibility that in certain circumstances the relationship between L. cruciata and G. proliferum be parasitic rather than symbiotic and open the door for future studies to ascertain the nature of liverwort-AM fungi relationships.
\end{abstract}

Key-words: Arbuscular mycorrhizal fungi; Phosphorus; Arum-type; Liverwort, Monoxenic cultures

\section{INTRODUCTION}

Arbuscular mycorrhizas (AM) are ubiquitous underground symbiotic associations between plants and obligate fungi of the phylum Glomeromycota (21). From this symbiosis plants generally obtain higher yields as they improve their capacity to acquire low mobile soil nutrients and increase resistance to biotic and abiotic stresses. Concomitantly the fungi are able to access the host photosynthate carbon pools and so to complete their life cycle $(1,15,23)$. Most available information on the physiology and anatomy of mycorrhizae is related to the sporophyte of Tracheophyta. Conversely for non-vascular plants the knowledge is still scarce. Within these the liverworts are an important and extremely successful group found in all continents and environments. Because liverworts are thought to be amongst the original colonisers of terrestrial habitats and appear to have remained relatively unchanged through time they probably hold the key to early terrestrial diversification of land plants $(17,18)$. Some complex thalloid liverworts
(Marchantiales) are known to form mycorrhiza-like associations with AM fungi. Mycothallus (3) develop structures that are analogous to those observed in AM roots, thus indicating possible functional similarities $(8,10,11,13,17,19)$. In these plants, as in roots, the AM fungus grows and connects two distinct environments: within the cells of the host body as inter or intracellular mycelium; and externally in the soil or medium matrix, thus extending the host plant capacity to access well beyond their body limits into the soil matrix. In roots the internal mycelium has been shown to have one or a combination of two different morphological types $(2,9,22)$ : Arum and Paris. The Arum-type morphology, first described on Arum maculatum, shows intercellular hyphae mainly growing longitudinally between cells with arbuscules rising on short upright intra-cellar branches. The Paris-type, originally described on Paris quadrifolia, is defined by cell-to-cell intracellular growth with the formation of coils and arbusculate coils. Depending upon the host plant and fungus these morph types can occur isolate or simultaneously within the same plant forming a continuous mycorrhizal structure

*Corresponding Author. Mailing address: Centre of Cellular Biology, Department of Biology, University of Aveiro, 3810-193, Aveiro, Portugal. Phone: +351-23437-0772; Fax: +351-23442-6408. E-mail: hfonseca@ua.pt 
(5). In liverworts the morphology of hyphae within mycothallus is not yet full characterised, however most reports indicate that AM fungi generally progresses within the plant body with patterns resembling the Paris-type $(6,11)$.

Phosphorus $(\mathrm{P})$ is an important macronutrient involved in key structural and metabolic functions of all organisms. Moreover, it is widely accepted that in many plants AM fungi plays the main role in the resistance to biotic and abiotic stresses by improving the host capacity to uptake major nutrients from soil, ex., inorganic phosphate (23). Although this is true for Tracheophyta the available information regarding nonvascular plants and particular those cultured in vitro is scarce or nonexistent (7). The nutrient requirements of liverworts vary considerably from those of most vascular plants.

The present work aims to address (i) the physiological effect of phosphorus on biomass production of $L$. cruciata colonisation by AM fungi, (ii) To survey the morph types of G. proliferum mycelium within L. cruciata thallus.

\section{MATERIALS AND METHODS}

\section{Biological material and growth conditions}

Glomus proliferum Dalpé \& Declerck (MUCL 41827), acquired from GINCO (Mycotheque de l'Université Catholique de Louvain, Laboratoire de Mycologie, Belgique) was multiplied and maintained in monoxenic cultures of Lunularia cruciata (L.) Dumortier ex. Lindberg. Plants and fungi were kept throughout the experiments at $25^{\circ} \mathrm{C}$ with a $10 / 14$ hours light/ dark photoperiod in a Sanyo MLR $-350 \mathrm{H}$ chamber with light of an average intensity of $68.3 \pm 6.4 \mu \mathrm{mol} \mathrm{s}^{-1} \mathrm{~m}^{-2}$ as described by Fonseca et al. (8).

\section{Inocula preparation}

Inocula were obtained from axenic and monoxenic thallus of L. cruciata cultured for 100 days on SRV (8) with $29.2 \mathrm{mM}$ sucrose, monoxenic cultures used showed profusion production of external hyphae and spores of G. proliferum (Fig. 1).

\section{Light microscopy}

To study the pattern of colonisation of L. cruciata by $G$. proliferum $0.5 \mathrm{~cm}$ thallus segments were cultured for 49 days on SRV medium as described by Fonseca et al. (8). The growth length of 44 mycothallus apices were measured weekly along an imaginary line through the thallus midrib (Fig. 2a). Measured segments were then cropped, fixed in Bouin's fluid and cleared with $10 \% \mathrm{KOH}$, at $80^{\circ} \mathrm{C}$ for $20 \mathrm{~min}$. Samples were washed in distilled water, acidified in $1 \mathrm{~N} \mathrm{HCl}$ before being dehydrated and embedded in paraffin wax. Sections of about $10 \mu \mathrm{m}$ were cut with a microtome (Leitz model 1512), mounted on microscope slides and stained overnight in $0.05 \%$ trypan blue (16). Images were digitally acquired with a Carl Zeiss Axiocam HR apparatus.

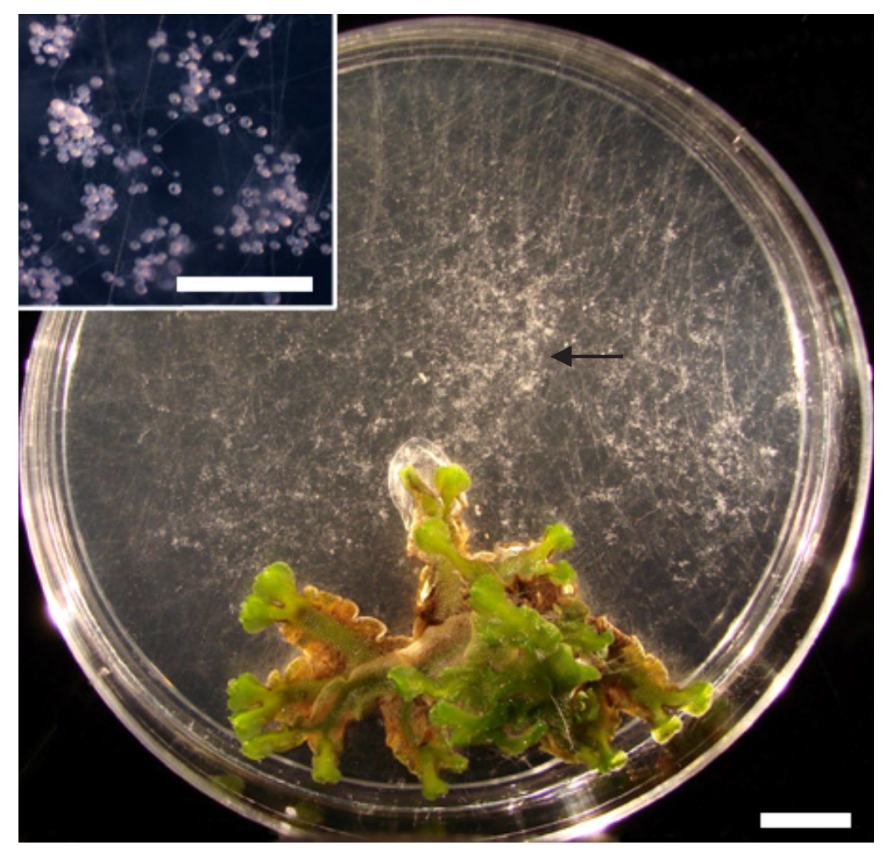

Figure 1. Maintenance culture of Lunularia cruciata with Glomus proliferum grown for 100 days in $30 \mathrm{ml} \mathrm{SRV} \mathrm{medium}$ with $29.2 \mathrm{mM}$ of sucrose and used as inocula source for the experiments. Plant discs sowed asymmetrically in Petri dishes allowed the fungus to grow undisturbed on more than half of dish area. (arrow) Indicates high concentration of hyphae and spore clusters with the inset showing external mycelium and spores imbedded in the medium. Bars $10 \mathrm{~mm}$; inset, $1 \mathrm{~mm}$.

\section{Phosphorus experiment}

Discs of thallus $\left(10.7 \pm 1.7 \mathrm{~mm}^{2}\right.$ made by $\varnothing 3.27 \mathrm{~mm}$ corkborers) from axenic and monoxenic $L$. cruciata were cultured for 70 days on $30 \mathrm{ml}$ of SRV (8) with $29.2 \mathrm{mM}$ sucrose and three levels of added phosphorus. A $2 \times 4$ factorial design was setup with the fungal treatment consisted of the presence $G$. proliferum and absence of fungus. The phosphorus treatment consisted of SRV media with three levels of added $\mathrm{KH}_{2} \mathrm{PO}_{4}$ (123.0, 61.5 and $30.7 \mu \mathrm{g} \mathrm{KH}_{2} \mathrm{PO}_{4}$ ) and SRV medium without added $\mathrm{KH}_{2} \mathrm{PO}_{4}$. There were ten replicate Petri dishes per treatment.

\section{Data collection}

Thallus length was estimated by engraving the contour of each thallus apex, under stereoscope microscope, on the lower side of the plastic Petri dish. At the end of the experiment the lines drawn along the thallus midrib were measured. Plant biomass was estimated as dry weight after oven-drying $\left(60^{\circ} \mathrm{C}\right)$ to a constant weight. Number of spores and hyphal length were measured under a stereomicroscope with a $6 \times 6$ square hairline 
graticule of $20.25 \mathrm{~mm}^{2}$ regularly placed at $0.5 \mathrm{~cm}$ intervals over the surface of inverted Petri dishes and following the method by McGonigle et al. (12). Data were evaluated for significance $(\mathrm{P}<0.05)$ using multivariate analysis of variance (ANOVA/ MANOVA) and post hoc Least Significant Differences test with Statistica software for Windows v4.5 (Statsoft Inc.).

\section{RESULTS}

\section{Effect of phosphorus}

The quantity of phosphorus present in Strullu-Romand (4) and SRV media is suitable for both axenic and monoxenic Ri TDNA transformed roots cultures colonised by AM fungi and for mycothallic L. cruciata. However, when added $\mathrm{P}$ is reduced by 50 or $75 \%$ from SRV levels no significant responses were observed on mycothallic $L$. cruciata dry weight and AM fungus hyphae and spore production (Table 1). Only when any $\mathrm{KH}_{2} \mathrm{PO}_{4}$ waCs added to the medium did plants show a decrease in biomass and the fungus presented a reduction in spore production,

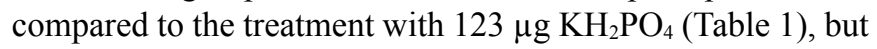
not for external hyphae length. Alternatively, if one analyses the data in terms of presence/absence of AM fungus colonisation the results shows that liverwort growth was negatively affected $(P<0.05)$ in monoxenic conditions. Colonised plants showed a reduction of $54.7 \%$ in dry weight, compared with axenic $L$. cruciata (Table 1).

\section{Thallus growth rate}

When cultured in $30 \mathrm{ml}$ of SRV (with $123 \mu \mathrm{g}$ of added $\mathrm{KH}_{2} \mathrm{PO}_{4}$ ) mycothallus of $L$. cruciata showed during the first 35 days a steady growth rate of $0.382 \mathrm{~mm} \cdot \mathrm{day}^{-1}\left(\mathrm{r}^{2}=0.999\right)$. From then on (the last 14 days of culture) the growth average rate decreased till about $13.1 \%$ at the end of the experiment (Fig. 2b) giving an overall average growth rate of $0.358 \pm 0.025$ $\mathrm{mm} \cdot$ day $^{-1}$ for 49 days culture.

\section{Anatomical characterisation of symbiosis}

L. cruciata is a complex thalloid liverwort with an internal differentiated anatomy (Fig. 2c). Intercellular hyphae were conspicuous throughout the mycothalli with few exceptions: hyphae were scarcely present among the small chlorophyllous cells within the photosynthetic layer; no fungus was observed in the meristematic zones on thallus apices; and, as reported by Fonseca et al. (8), no hyphae colonised rhizoid cells. Conversely, G. proliferum was profusely present within the highly vacuolated parenchyma cells with special prevalence in the central midrib area where trypan blue stain revealed a distinct fungal layer (Fig. 2c). Within this layer a denser network of internal hyphae could be seen connecting arbuscules, coils and arbusculate coils, as well as, scattered vesicles. Hyphae and arbuscules were also present in oil cells (Fig. 2d). The morphological type of $L$. cruciata colonisation by G. proliferum was predominantly

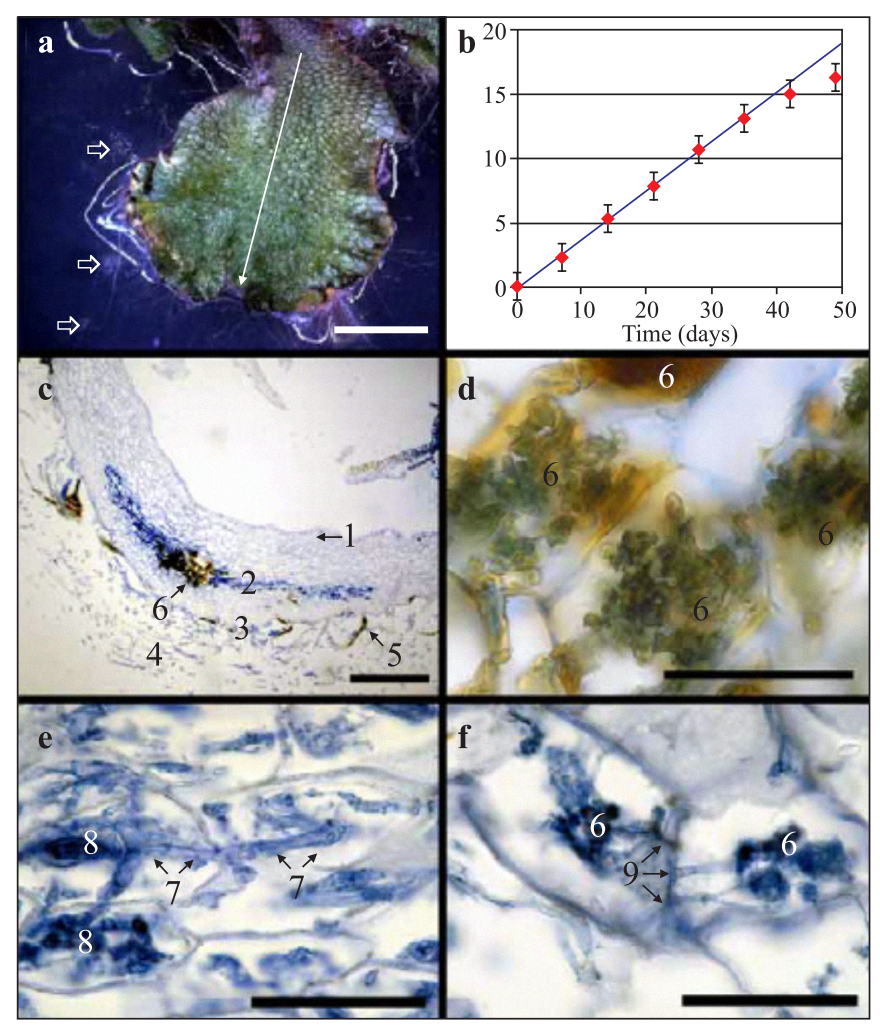

Figure 2. Lunularia cruciata colonised by Glomus proliferum grown for 49 days on SRV medium with $29.2 \mathrm{mM}$ of sucrose. (a) Mycothallus apex showing midrib imagine line arrow used for the last measurement of thallus length. (open arrows) Spore clusters imbedded in the medium. (b) Mycothallic averages and standard deviations (vertical bars) of growth length of 44 apices measured at 7 days intervals. Fitted line and equation describes the lengthening pattern of mycothallus during the first 35 days of growth. Equation: $y$, Length (mm); $x$, Time (days); $r 2$, R-squared value. ( $c$ to $f$ ) Light microscopy of trypan blue-stained samples: (c) Anatomic section of mycothallus showing (1) photosynthetic layer under an upper epidermis; (2, fungal layer) thallus' midrib parenchyma with high concentration of arbuscules, vesicles and oil cells; (3) the lower epidermis with (4) rhizoids and (5) scales; $(d)$ Arbuscules within (6) oil cells located in the thallus' midrib parenchyma. These cells show their oily content only partially removed by the method for microscopy. (e) Small section of mycothallus midrib anatomy exemplifies a common morphological pattern showing (7) hyphae crossing cell-to-cell in a pattern characteristic of the Paris-type. (8) Arbusculate coils. (f) The less frequent morphology of Arum-type was also present in some cluster of cells within the thallus midrib showing several (6) overlapping arbuscules connected to (9) hyphae progressing close to liverwort cell wall. Bars: (a) $5 \mathrm{~mm}$; (c) 200 $\mu \mathrm{m}$; (d) $50 \mu \mathrm{m}$; (e, f) $20 \mu \mathrm{m}$. 
Table 1. Biomass, number of fungal spores and hyphae length production of Lunularia cruciata, cultured for 70 days in $30 \mathrm{ml}$ of SRV medium with $29.2 \mathrm{mM}$ sucrose, with and without Glomus proliferum and with different levels of added $\mathrm{KH}_{2} \mathrm{PO}_{4}$ plus without added phosphorus. Yes - plants colonised by G. proliferum; No - axenic L. cruciata.

\begin{tabular}{ccccc}
\hline G. proliferum & $\mathrm{KH}_{2} \mathrm{PO}_{4}(\mu \mathrm{g})$ & Dry weight $(\mathrm{g})$ & Number of spores & Hyphae length $(\mathrm{mm})$ \\
\hline Yes & 0.0 & $0.066 \pm 0.017 \mathrm{a}$ & $11038 \pm 9232 \mathrm{a}$ & $69805 \pm 41445 \mathrm{a}$ \\
Yes & 30.8 & $0.082 \pm 0.010 \mathrm{ab}$ & $12766 \pm 6966 \mathrm{a}$ & $75937 \pm 38726 \mathrm{a}$ \\
Yes & 61.5 & $0.074 \pm 0.032 \mathrm{ab}$ & $25940 \pm 15216 \mathrm{ab}$ & $72975 \pm 48888 \mathrm{a}$ \\
Yes & 123.0 & $0.091 \pm 0.023 \mathrm{~b}$ & $54749 \pm 34710 \mathrm{~b}$ & $135278 \pm 73912 \mathrm{a}$ \\
No & 0.0 & $0.131 \pm 0.030 \mathrm{c}$ & - & - \\
No & 30.8 & $0.159 \pm 0.025 \mathrm{c}$ & - & - \\
No & 61.5 & $0.129 \pm 0.016 \mathrm{c}$ & - & - \\
No & 123.0 & $0.153 \pm 0.027 \mathrm{c}$ & - & - \\
\hline
\end{tabular}

Means ( \pm Standard deviation) followed by the same letter do not differ significantly $(\mathrm{P}<0.05)$.

of the Paris-type (9,22) (Fig. 2e), however in places the hyphae and arbuscules denoted a pattern closest related to the Arumtype morphology (Fig. 2f). Here the hyphae appear to grow close to the plant cell wall with arbuscules rising on short upright intra-cellular branches.

\section{DISCUSSION}

The cultures used as inoculum for the experiments had their origin in 2003 (8). Since then they have been regularly subcultured producing a reliable means to maintain and multiply $G$. proliferum. In addition, the use of $L$. cruciata as host for AM fungi has the advantage, over the Ri T-DNA transformed root systems as they allow easy crop and manipulation of the external mycelium. With these cultures the plants usually occupy less than half the Petri dish area and sometimes leaving undisturbed $3 / 4$ of available medium surface with no apparent adverse effect on external mycelium growth (Fig. 1).

In vitro cultured $L$. cruciata with and without $G$. proliferum behaved indifferently to changes in medium added P. Both plant dry weight and AM fungi growth (number of spores and external hyphae length) could not resolve significant changes with these used levels of $\mathrm{KH}_{2} \mathrm{PO}_{4}$ that is in accordance with the capacity of liverworts to exhibit normal development on wide range of media (7). A different plant and fungus behaviour was observed when any $\mathrm{KH}_{2} \mathrm{PO}_{4}$ was added to the SRV medium. For these plants there were trace amounts of $\mathrm{P}$ derived from residual $\mathrm{P}$ brought by the initial plant inoculum (thallus discs) and by medium Phytagel ${ }^{\mathrm{TM}}$ component (14). Because differences in plant and fungal growth were observed between treatments where any and the maximal $\mathrm{KH}_{2} \mathrm{PO}_{4}$ was used, we may speculate that the limiting threshold for $\mathrm{P}$ to induce differences in plant and AM fungal behaviour lay above residual $\mathrm{P}$ present in the experiment. Moreover, in the present culture conditions, the plant overall growth pattern strongly suggests that the colonisation of $L$. cruciata by AM fungi is a heavy burden for the plant growth thus implying that the colonisation of $L$. cruciata by $G$. proliferum is not a mutualistic symbiosis but rather a parasitic one. However, the anatomical traits observed in this association are consistent with those present in mycorrhizae colonised by G. proliferum. The liverwort may gain from the association only if important nutrients, such as phosphorus, are directly unavailable to the plant or if available they are below the optimum threshold for maximal mycothallus growth.

Considerations about the morphotype of G. proliferum growth within $L$. cruciata thallus were already raised by Fonseca et al. (8). At the time it was suggested that the architecture $G$. proliferum was more consistent with the Paris-type. Our extensive survey of mycothallus of $L$. cruciata agrees with this assertion. The fungus colonises almost all parts of the thallus except areas close to the meristematic zones. In this survey any information was gathered on the presence of AM fungi in reproductive structures (sexual and asexual) because the photoperiod imposed to the cultures was conducive to the absence of those structures. Our study also confirms findings reported by Fonseca et al. (8) that G. proliferum hyphae and arbuscules were present in oil cells and absent from rhizoids. Although the converse was described for other liverworts $(11,19)$ the persistent absence of rhizoids from in vitro studies of liverworts and hornworts (20) may indicate that the diffuse presence of light in vitro within the medium and all over the plant excludes the rhizoids from being the principal source of plant colonisation. Within the thallus midrib, the trypan blue staining revealed a layer of intense marked cells where colonisation by G. proliferum formed a zone rich in arbuscules, coils, arbusculate coils and other AM anatomical traits. The predominant morphotypes are consistent with the Paris-type as the hyphae were observed to progress from cell to cell and, particularly within the midrib fungal layer, numerous arbuscules 
and coils were present. However scattered within the AM fungal zone of the parenchymatous layer one occasionally observed clusters of cells where the fungi appear to progress in a mode more consistent with the Arum-type.

\section{CONCLUSIONS}

From the observations in this study and from those of an earlier study on mycothallus of $L$. cruciata (8) we propose that the colonisation by G. proliferum not only has the major mycorrhizal traits generally associated with the colonisation of roots by AM fungi (arbuscules, coils, arbusculate coils and vesicles), but it also shows that the internal hyphae colonises the thallus predominantly with a Paris morphotype. Furthermore, the colonisation of $L$. cruciata by G. proliferum resulted in a reduction of host biomass compared with axenic plants suggesting a bypass of resources towards the fungus. Hence the relationship between L. cruciata and G. proliferum may not always be, if ever, symbiotic in nature. Finally, the present study shows that, despite any response from $L$. cruciata to changes in medium above $30.7 \mu \mathrm{g} \mathrm{KH}_{2} \mathrm{PO}_{4}$, the $\mathrm{P}$ stress observed in mycothallus when any $\mathrm{P}$ was added indicates that the threshold for optimum growth is above the residual amounts of $\mathrm{P}$ brought by contaminants in Phytagel ${ }^{\mathrm{TM}}$ and $\mathrm{P}$ in the plant inoculum. This finding opens the door for future nutritional studies to ascertain the nature of liverwort-AM fungi relationships.

\section{ACKNOWLEDGEMENTS}

The authors would like to thank Dr. Lourdes Pereira and Dr. Manuel Santos for the use of their Laboratory facilities; acknowledge the financial support of Fundação para a Ciência e a Tecnologia (SFRH/BSAB/740/2007), Portugal and a fellowship grant from Inter-American Institute for Global Change Research (IAI) CRN II/14 which is supported by the US National Science Foundation (Grant GEO-04523250)

\section{RESUMO}

\section{Predomínio da morfologia tipo-Paris em talo de Lunularia cruciata colonizado por Glomus proliferum}

Observações de microscopia ótica confirmam que $L$. cruciata colonizada por G. proliferum apresenta caracteres anatomicos (arbúsculos, hifas novelas, arbúsculos enovelados e vesículas) geralmente associadas a raízes micorrízicas arbusculares em que $o$ micélio intra-tálico apresenta uma anatomia predominantemente do tipo Paris. L. cruciata colonizada apresentou redução de biomassa quando comparada com plantas axenicas, sugerindo dreno de recursos para o fungo e consequente redução de nutrientes necessários para o ótimo crescimento da planta. $\mathrm{O}$ comportamento do talo-colonizado em relação à disponibilidade de $\mathrm{KH}_{2} \mathrm{PO}_{4}$ no meio indica que o limiar de stress nutricional para fósforo se encontra acima do somatório das quantidades residuais deste elemento presentes no Phytagel ${ }^{\mathrm{TM}}$ e no inóculo. Os resultados aqui discutidos sugerem a possibilidade de, em certas circunstâncias, a relação entre L. cruciata e G. proliferum ter características de parasitismo e não de simbiose, abrindo novas perspectivas para futuros estudos na determinação da natureza da relação hepática-fungo arbuscular.

Palavras chave: Fungos micorrízicos arbusculares; Fósforo; Tipo-Arum; Briófitas; Culturas monoxênicas.

\section{REFERENCES}

1. Bago, B.; Pfeffer, P.E.; Shachar-Hill Y. (2000). Carbon metabolism and transport in arbuscular mycorrhizas. Plant Physiology, 124, 924-957.

2. Berbara, R.L.L.; Souza, F.A.; Fonseca, H.M.A.C. (2006). III - Fungos micorrízicos arbusculares: muito além da nutrição. In: Fernandes, M.S. (ed.) Nutrição mineral de plantas. Sociedade Brasileira de Ciência do Solo, Viçosa, MG, p. 74-85.

3. Boullard, B. (1988). Observations on the coevolution of fungi with hepatics. In Pirozynski, K.A.; Hawksworth, D.L. (eds) Coevolution of Fungi with Plants and Animals, Academic Press, London, p. 107124.

4. Declerck, S.; Strullu, D.G.; Plenchette, C. (1998). Monoxenic culture of the intraradical forms of Glomus sp. isolated from a tropical ecosystem: a proposed methodology for germplasm collection. Mycologia, 90, 579-585.

5. Dickson, S. (2004). The Arum-Paris continuum of mycorrhizal symbioses. New Phytologist 163, 187-200.

6. Dickson, S.; Smith, F.A.; Smith, S.E. (2007). Structural differences in arbuscular mycorrhizal symbioses: more than 100 years after Gallaud, where next? Mycorrhiza, 17, 375-393.

7. Duckett, J.G.; Burch, J.; Fletcher, P.W.; Matcham, H.W.; Read, D.J.; Russell, A.J; Pressel, S. (2004). In vitro cultivation of bryophytes: a review of practicalities, problems, progress and promise. J. Bryol., 26, 3-20.

8. Fonseca, H.M.A.C.; Berbara, R.L.L.; Pereira, M.L. (2006). Lunularia cruciata a potential in vitro host for Glomus proliferum and $G$. intraradices. Mycorrhiza, 16, 503-508.

9. Gallaud, I. (1905). Études sur les mycorrhizes endotrophes. Revue General de Botanique, 17, 5-500. [Cited in Kubota, M.; Terence P.; McGonigle T.P.; Hyakumachi M. (2005). Co-occurrence of Arumand Paris-type morphologies of arbuscular mycorrhizae in cucumber and tomato. Mycorrhiza, 15, 73-77].

10. Kottke, I.; Nebel, M. (2005). The evolution of mycorrhiza like associations in liverworts: an update. New Phytologist, 167, 321323.

11. Ligrone, R.; Carafa, A.; Lumini, E.; Bianciotto, V.; Bonfante, P.; Duckett, J.G. (2007). Glomeromycotean associations in liverworts: a molecular, cellular, and taxonomic analysis. Am. J. Bot., 94, 17561777.

12. McGonigle, T.P.; Miller, M.H.; Evans, D.G.; Fairchild, G.L.; Swan, J.A. (1990). A new method which gives an objective measure of colonization of roots by vesicular-arbuscular mycorrhizal fungi. New Phytologist, 115, 495-501.

13. Nebel, M.; Kreier, H.P.; Preussing, M.; Weiss, M.; Kottke, I. (2004). Symbiotic fungal associations of liverworts are the possible ancestors of mycorrhizae. In Agerer, R.; Piepenbring, M.; Blanz, P. (ed.) Frontiers in Basidiomycote Mycology. IHW-Verlag. p. 339-360. 
14. Nielsen, J.S.; Joner, E.J.; Declerck, S.; Olsson, S.; Jakobsen, I. (2002). Phosphoimaging as a tool for visualization and non invasive measurement of $\mathrm{P}$ transport dynamics in arbuscular mycorrhizas. New Phytologist, 154, 809-818.

15. Pfeffer, P.E.; Douds, Jr D.D.; Bücking, H.; Schwartz, D.P.; ShacharHill, Y. (2004). The fungus does not transfer carbon to or between roots in an arbuscular mycorrhizal symbiosis. New Phytologist, 163 , 617-627.

16. Phillips, J.M.; Hayman, D.S. (1970). Improved procedures for clearing roots and staining parasitic and vesicular-arbuscular mycorrhizal fungi for rapid assessment of infection. Trans Br Mycol Soc., 55, 158-161.

17. Read, D.J.; Duckett, J.G.; Francis, R.; Ligrone, R.; Russell, A. (2000). Symbiotic fungal associations in 'lower' land plants. Phil. Trans. R. Soc. London B, 355, 815-831.
18. Renzaglia, K.S.; Schuette, S.; Duff, R.J.; Ligrone, R.; Shaw, A.J.; Mishler, B.D.; Duckett, J.G. (2007). Bryophyte phylogeny: Advancing the molecular and morphological frontiers. The Bryologist, 110, 179. 213.

19. Russell, J.; Bulman, S. (2005). The liverwort Marchantia foliacea forms a specialized symbiosis with arbuscular mycorrhizal fungi in the genus Glomus. New Phytologist, 165, 567-579.

20. Schüßler, A. (2000). Glomus claroideum forms an arbuscular mycorrhiza-like symbiosis with the hornwort Anthoceros punctatus. Mycorrhiza, 10, 15-21.

21. Schüßler, A.; Schwarzott, D.; Walker, C. (2001). A new fungal phylum, the Glomeromycota: phylogeny and evolution. Mycol. Res., 105, 1413-1421.

22. Smith, F.A.; Smith, S.E. (1997). Structural diversity in (vesicular)arbuscular mycorrhizal symbiosis. New Phytologist, 137, 373-388.

23. Smith, S.E.; Read, D.J. (1997). Mycorrhizal symbiosis, $2^{\text {nd }}$ edn. San Diego, CA, USA, Academic Press. 